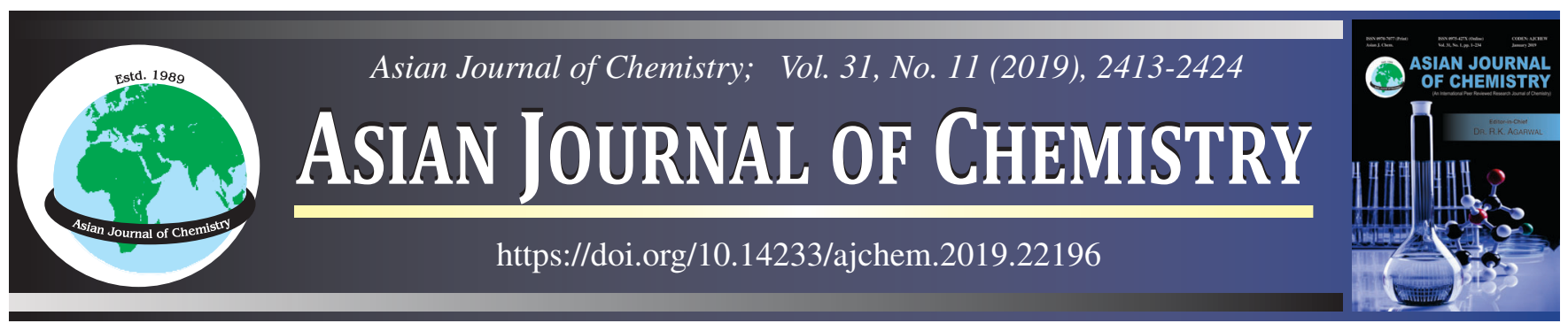

REVIEW

\title{
Biomethane Production from Anaerobic Codigestion of Palm Oil Mill Effluent with Cattle Manure: A Review
}

\author{
B.K. Zaied ${ }^{1}$, M.N.I. SiddiQue ${ }^{2, *}$, A.W. Zularisam ${ }^{1}$, M.F. AhMAD² and Y.M. SAliH ${ }^{2}$
}

${ }^{1}$ Faculty of Engineering Technology, Universiti Malaysia Pahang (UMP), 26300 Gambang, Kuantan, Pahang, Malaysia

${ }^{2}$ School of Ocean Engineering, Universiti Malaysia Terengganu (UMT), 21030 Kuala Nerus, Terengganu, Malaysia

*Corresponding author: Fax: +60 9 5493006; Tel: +60 9 6683614; E-mail: m.nurul@umt.edu.my

Received: 13 May 2019;

Accepted: 3 July 2019;

Published online: 28 September 2019;

AJC-19562

\begin{abstract}
Biogas is conventionally utilized in a gas engine to convert the chemical energy into electricity and into thermal energy for heating purposes and is also pumped into the natural gas grid line after impurities are removed. Biogas production from palm oil mill effluent is one of the best options for economic expansion and this would reduce environmental impacts in developing countries like Malaysia. This study aims to perform an analysis of the economic and environmental prospects of biogas production from the anaerobic codigestion method from palm oil mill effluent mixed with cow manure. Anaerobic codigestion technology is considered a practical process by which to overcome the complications of substance properties and system optimization in particular substance digestion operations. Comparisons among various treatment technologies of palm oil mill effluent and their applications have been studied thoroughly. The factors that affect biogas production, along with strategies for their improvement, were studied in present report. The economic feasibility of biogas plant where palm oil mill effluent and cattle manure are main substrates and anaerobic codigestion is the method, has been successfully predicted. Results revealed this might be more feasible if this technology is used on a large scale. Construction of the proposed biomethanization plant is economically feasible because it is projected that about a four-year return-on-investment will be achieved. In conclusion, the present work demonstrates a comprehensive feasibility framework by which to integrate the different features needed to enhance biomethane generation.
\end{abstract}

Keywords: Feasibility analysis, Biogas production, Anaerobic codigestion, Palm oil mill effluent, Cattle manure.

\section{INTRODUCTION}

Nowadays, the Southeast Asia region is dominating the palm oil industry. Especially in Malaysia, a significant agronomic product is palm oil after introduction in this area since the $14^{\text {th }}$ century due to its aptness to provincial climatic environments and greater production rates [1]. Being core fiscal driver and vital component of GDP, in 2011 over 17 million metric tons palm oil cultivated, which have been possible by palm oil plantations in Malaysia [2]. Recently, 21,000 metric tons palm oil are being manufactured in Malaysia [3]. In 2017, Malaysia had 453 nos operating mills where 130 nos in Sabah, 80 nos in Sarawak and other 244 nos mills in Peninsular (MPOB, 2017).

Though it has a dynamic role in the economy of Malaysia, it is facing numerous difficulties that lessen its competitiveness.
By pumping and distributing water, unindustrialized actions consume greater energy and to produce a huge amount of extremely contaminating waste substances, which has greater valuable biological substance and moistness, the palm oil industry is liable. Mainly, palm oil mill which produces vast quantities of palm oil mill effluent (POME) is a combination of undergrowth wastewater produced during various steps of palm oil yields procedure besides the clean water used in washing the services. In POME, there are several suspended and dissolved elements producing awful smells after digestion. Processing of palm oil is washed out by huge amount of water from mills where the palm fruits extract oil. Palm oil mill effluent is the resultant of about $50 \%$ of these waters, which came from the crude palm oil (CPO) of fresh fruits. It is projected that about 5-7.5 tons of water become POME during the production

This is an open access journal, and articles are distributed under the terms of the Attribution 4.0 International (CC BY 4.0) License. This license lets others distribute, remix, tweak, and build upon your work, even commercially, as long as they credit the author for the original creation. You must give appropriate credit, provide a link to the license, and indicate if changes were made. 
of 1 tonne of crude palm oil [4]. 18.7 million tons crude palm oil were produced in 2012 (MPOB, 2013). The resultant for such amount of crude palm oil production is huge amount of POME and it is almost three times the quantity of crude palm oil production [5]. If discharged directly into the waterways, the environment will be polluted by POME because of its greater carbon rich organic properties. Empty fruit bunches, palm kernel and palm fibre are the solid waste substance resulting from milling operation. These solid waste products are being used for economically advantageous purposes like mulch in agriculture and fuel material both in traditional and modern milling settings, but it is discharging only the POME into the environment, either raw or treated.

Palm oil mill effluent has mostly acidic character having greater dissolved solids content and its degradation is quite difficult. On the other hand, the enormous quantity of cattle manure $(\mathrm{CM})$ is being produced at present, which also causes greater damage to the environment [6]. The anaerobic digestion is achieved by microbe consortium and mostly be subjected to different factors like $\mathrm{pH}$, temperature, hydraulic retention time (HRT), carbon to nitrogen proportion and it has a comparatively slow process [7]. An important method is codigestion, which is capable of increasing biogas production. However, as an exceptional inoculum in the anaerobic digestion, cattle manure contains prominent buffering capacity, anaerobic bacteria abundance and an extensive range of important nutrients for the optimum growing of microbial consortium [8]. Consequently, its implementation with POME during anaerobic digestion as an inoculum is favourable as the energy source is delivered where simultaneously the pollution risk is being resolved which is accompanied by cattle manure [9]. Earlier, many research scientists testified codigestion of POME by several inoculums [10]. Codigestion of POME with cattle manure for biogas production is so inadequate. At present, the study of the prospective cattle manure investigation has now started as inoculums from POME for biogas production with controlled $\mathrm{pH}$ and temperature.

For better biogas production rate, codigestion method is broadly used. Codigestion is the instantaneous digestion of more than two substrates for the improvement of process efficiency. It is a promising preference to overwhelm the difficulties of single digestion and expand the fiscal feasibility of the anaerobic digestion industry because of advanced biogas yields [7]. Biogas generation enhancement is the main benefit of anaerobic codigestion (AcoD) procedure. For the greater biogas production, it can be found subsequent beneficiaries by $\mathrm{ACoD}$ i.e., steadiness improvement, inhibitory elements watering, stable nutrient, essential moistness innards achievement, reduction of the greenhouse gases produced, a load of recyclable biological substance growing and economic returns from the statistic of allotted device and price. For the function of the biogas production, codigestion is the crucial feature alike pretreatment. All through the codigestion procedure, it should accomplish more than two biological constituents appropriately to upsurge biogas production.

The ACoD technology uses various organic wastes for the development of biogas production with POME is shown in Table-1. ACoD of POME and cattle manure produces the maximum biogas where POME and oil palm fronds generates minimum biogas. For the system imbalance and methane yields reduction, inappropriate choice of substrates, arrangements and working conditions are responsible. Therefore, a comprehensive scientific model for ACoD technology is required for the experimental based study and full-scale strategy and action which can forecast effects of mixing proportion of substrates, organic loading rates and appropriate system for wastewaters treatment [11]. Recently, researchers are investigating and experimenting with the $\mathrm{ACoD}$ method because it has greater feasibility and appropriateness for the development of biogas production and environmental sustainability [12].

For future renewable energy (RE) production, POME has the potential to become the main source because it can be considered an advantage over the wind, solar and mini-hydro due to its amount, constancy and accessibility as it is found from the current palm oil industry. In the Malaysian Five-Fuel Policy since 2001, renewable energy has been included and that's why it is necessary to commence a feasibility study on the founding of a POME biogas plant. Useful research and investigation of factors affecting $\mathrm{ACoD}$, proper arrangements of operational parameters and optimization techniques are still imprecise. However, there is no feasibility analysis has been studied till to date for the biogas production from $\mathrm{ACoD}$ of POME and cattle manure in Malaysia. This novel utilization of biogas in the widely held of ACoD plants are being used to produce electric power and heat concurrently, but limited research is available in specific journals that represent outcome about the motorized use of biogas. $\mathrm{L} \mathrm{CH}_{4} \cdot \mathrm{g} \mathrm{COD}_{\text {removed }}{ }^{-1} \mathrm{~d}^{-1}$

This paper aims to review the feasibility analysis of $\mathrm{ACoD}$ of POME and cattle manure, governing the functional conditions that exploit the biogas production, application of cleaner and more effective methods in palm oil industry, estimation of the methodological, economical effective and environment friendly use of POME and cattle manure as biogas inoculums and promotion of circular budget and renewable energy procession. This paper is mostly focused on the analysis of economic and environmental friendly of biogas production from $\mathrm{ACoD}$ of POME and cattle manure. This study acts as a precursor to investigate the possible positive and negative outcomes of different treatment technologies before investing too much time, money and consideration of an environmental effect. In

TABLE-1

COMPARISON OF CODIGESTION OF POME BY VARIOUS SUBSTRATE AND METHANE YIELDS

\begin{tabular}{llcl}
\hline \multicolumn{1}{c}{ Substrate } & \multicolumn{1}{c}{ Condition (temp., $\left.{ }^{\circ} \mathrm{C}\right)$} & Methane yields $(\mathrm{mL} / \mathrm{g} \mathrm{VS}$ added & Ref. \\
\hline Palm oil mill effluent and cattle manure & Mesophilic (37) & 1875 & 392 \\
Palm oil mill effluent and empty fruit brunches & Mesophilic (37) & 456 & {$[87]$} \\
Palm oil mill effluent and sewage chemical sludge & Mesophilic (37) & 207 & {$[88]$} \\
Palm oil mill effluent and oil palm fronds & Thermophilic (55) & 391 & {$[89]$} \\
Palm oil mill effluent and decanter cake & Thermophilic (55) & {$[90]$} & \\
\hline
\end{tabular}


GENERAL CHARACTERISTICS OF POME (MEAN \pm STANDARD DEVIATION OF THREE VALUES) [Ref. 36]

\begin{tabular}{lclc}
\hline \multicolumn{1}{c}{ Parameter } & Concentration & \multicolumn{1}{c}{ Metals } & Concentration $(\mathrm{mg} / \mathrm{L})$ \\
\hline COD $(\mathrm{mg} / \mathrm{L})$ & $50000 \pm 300$ & Potassium & $1604 \pm 50$ \\
BOD $(\mathrm{mg} / \mathrm{L})$ & $27000 \pm 200$ & Calcium & $340 \pm 30$ \\
Total solid $(\mathrm{mg} / \mathrm{L})$ & $45000 \pm 300$ & Magnesium & $295 \pm 30$ \\
Total suspended solid $(\mathrm{mg} / \mathrm{L})$ & $29500 \pm 200$ & Phosphorus & Manganese \\
Total volatile solids $(\mathrm{mg} / \mathrm{L})$ & $40000 \pm 300$ & Iron & $112 \pm 20$ \\
Total nitrogen $(\mathrm{mg} / \mathrm{L})$ & $750 \pm 100$ & Zinc & $3.2 \pm 0.2$ \\
Oil and grease $(\mathrm{mg} / \mathrm{L})$ & $8000 \pm 200$ & Copper & $118 \pm 30$ \\
Temperature $\left({ }^{\circ} \mathrm{C}\right)$ & $85 \pm 0.2$ & Chromium & $1.5 \pm 0.1$ \\
pH & $4 \pm 0.4$ & Cobalt & $1.2 \pm 0.1$ \\
Colour $(\mathrm{ADMI})$ & $>500$ & & $0.24 \pm 0.01$ \\
\hline
\end{tabular}

this paper, it represents the significance and perceptions on the procedure of biogas yields as well as suggests a few convenient phases for more cost-effective and eco-friendly progress of ACoD systems by POME and cattle manure.

\section{Characteristics of substrates}

Palm oil mill effluent (POME): Palm oil industry generates vast amounts of POME. A huge amount of water is necessary for removing crude palm oil (CPO). Around 1.5 cum of water are needed per ton for treating of fresh fruit bunches (FFB) where nearly $50 \%$ of the used water become POME [13]. The raw POME is like high brownish, viscid and large colloquial substances, water containing is $95-96 \%$, including total solids, are 4-5\%, suspended solids are 2-4\% and oil and grease are $0.6-0.7 \%$ which discharge temperature is $80-90{ }^{\circ} \mathrm{C}$. Palm oil mill effluent is acidic too [14]. Palm oil mill effluent contains many amino acids, inorganic nutrients, short fibres, nitrogenous mixtures, starches and free biological acids [15]. Its $\mathrm{pH}$ value is low and nitrogen found as total nitrogen (TN) [16]. Organic matters are lignin, phenolics, pectin and carotene [17]. It is non-toxic and spread unfavourable odour but contain high chemical oxygen demand (COD) and biological oxygen demand (BOD) values and affects adversely on the environment. Table-2 is showing the characteristics of raw POME.

Cattle manure (CM): The cattle manure has been scrutinized by their properties. The results have been provided in Table-3. At present, farm digesters are operating at total solid between 8 and $12 \%$ as the total solid content is less therefore minor dilution is required [18]. Additionally, if we add the seed sludge, it increases the solid content at the beginning of digestion. In theory, a high yield of biogas will be produced by high volatile solids, which is applied at the optimum condition in the digester. Organic nitrogen with only $800 \mathrm{mg} / \mathrm{L}$ as ammonia nitrogen form can ascribe high content of $9.3 \mathrm{~g} / \mathrm{L}$ of the total nitrogen. It should be careful when biomass is being contained by digesting high nitrogen because free ammonia transformation may cause toxicity to the bacteria. Free ammonia can pass over the microbe's cell film which causes proton inequity and potassium shortage [19].

Microbial growth during $\mathrm{ACoD}$ of waste requires sodium, potassium and other cationic elements. However, if they exist at too high concentrations they can be inhibitory to microbial activity [20]. The treatment process is positively affected by the presence of metals because of their low percentage. Cattle
TABLE-3

COMPOSITION OF FRESH UNDILUTED CATTLE MANURE $(\mathrm{MEAN} \pm$ STANDARD DEVIATION OF THREE VALUES) [Ref. 91]

\begin{tabular}{lc}
\multicolumn{1}{c}{ Types } & Values \\
\hline COD (mg/L) & $17400 \pm 200$ \\
BOD (mg/L) & $10000 \pm 100$ \\
Total solid (\% wt) & $16.7 \pm 0.05$ \\
Total nitrogen $(\mathrm{mg} / \mathrm{L})$ & $9260 \pm 100$ \\
Volatile solids $(\mathrm{mg} / \mathrm{L})$ & $1187.9 \pm 12$ \\
Phosphorus $(\mathrm{ppm})$ & $24.7 \pm 0.2$ \\
Potassium $(\mathrm{ppm})$ & $44.2 \pm 0.5$ \\
Calcium $(\mathrm{ppm})$ & $65.9 \pm 0.5$ \\
Magnesium $(\mathrm{ppm})$ & $14.7 \pm 0.2$ \\
Iron (ppm) & $10.3 \pm 0.2$ \\
Sodium (ppm) & $3.9 \pm 0.1$ \\
Aluminium (ppm) & $2.6 \pm 0.1$ \\
Carbon $(\%$ wt dry basis) & $43.5 \pm 0.5$ \\
Hydrogen $(\%$ wt dry basis) & $5.47 \pm 0.1$ \\
Oxygen $(\%$ wt dry basis) & $49.2 \pm 0.5$ \\
\hline
\end{tabular}

manure elemental analysis indicates large amounts of oxygenated compounds, perhaps due to the nature of the food cattle consume. Generally, palm kernel cake (PKC), spent brewer grain (wheat and barley) and soy residue are in cattle feeds. Palm kernel cake is made from the leftovers from palm kernel oil milling and contains $14-16 \%$ of crude protein, whereas soy residue contains around $16 \%$ protein and spent brewer grain contains $28 \%$ protein [21]. Palm kernel cake also contains oil (between 5 and $12 \%$ ). However, the presence of oil is not significant; it may be a high part of the lipid content in the manure. The cattle may not be able to digest fully the carbohydrates in the feed in their stomachs, so the rest of the carbohydrates may ensure that considerable oxygen content remains.

POME treatment technologies: Valuable materials can get from nitrogenous elements, the greater amounts of protein, lipid, starch and minerals in POME by using a microbial procedure [22]. Anaerobic digestion is the most appropriate procedure for POME treatment because it has organic possessions. Thus, the palm oil mill industry is using ponding method as the general technique for the treatment of POME [23]. However, it is necessary to give full consideration for some portions of POME to make sure that the industry will stay as a workable and ecologically friendly. Because of its non-lethal characteristics, POME treatment is the essential part to make sure a balance among the environmental safety, economic development and sustainable progress because it causes pollution rapidly because of its non-lethal characteristics. Palm oil mill 
effluent treatment is the essential part to make sure a balance among the environmental safety, economic development and sustainable progress because it causes pollution rapidly [24]. But, the treatment is considering as hindrance relatively considering as a production procedure part and became a source for many advantages [16]. By the direct release of POME into the river or natural water will affect water pollution and result in hazardous water [25]. Therefore, researchers and scientists are doing various experiments for the proper treatment of POME. Following are the different and most used treatment methods for the POME.

Aerobic-anaerobic treatments: To maintain liquor distribution and biogas production by acquiring a large area, it creates offensive odour, which is responsible for the detrimental effect of the environment. In Malaysia, the palm oil industries must have an open container or pond essentially for happening anaerobic digestion. Palm oil mill effluent is usually made up of organic, biodegradable substance that's why the most suitable process for the treatment is formed on the anaerobic, aerobic and facultative procedure [26]. The reason for greater degradable organic substance in fresh POME is worse palm oil existence [4]. Organic action is more advantageous than another method because of its energy requirement, the least sludge growth, no deliverance of unwanted smell and methane yields by effective failure of organic elements with anaerobic microbes [27]. After that, produced methane gas is being utilized as renewable energy. Unluckily, the anaerobic pond system mostly depends on microbes to degrade the organic substances. For assurance, a supportive area for the microbes which is good for growing well is remarkably gentle to the surrounding environment [4].

Conversely, the main difficulty for open pond method is the independence of biogas emissions easily to the environment, which gradually affects ozone stratum by making it thinner and finally becomes a reason for the greenhouse effect. Though a small investment and operational energy are required for these procedures, these have a longer HRT and need a big land zone for the functioning procedure [28]. The closed system minimizes water pollution and biogas production and collection can be used as renewable energy like electric power production [29]. Also, palm oil industries can get carbon back by full use of produced methane gas from the codigestion of POME [10].

Coagulation/flocculation treatment: The physicochemical action, which is being used for POME treatment uses a substance, for instance, coagulants or flocculants focusing mostly on the taking apart from colloidal elements. There are various treatment procedures of physicochemical action for the treatment of POME, which requires a high quantity of substances and alone it has no use on a useful measurement. These substances will correct the condition of the mixture, which will allow them to stay immovably stable such as a particle or flocs. Coagulation or flocculation use is being utilized as pretreatment every time as its capability to reduce the total suspended solids (TSS) of the wastewater and by this, it is easy to proceed in the next stage.

$\mathrm{FeCl}_{3}, \mathrm{AlCl}_{3}, \mathrm{Al}_{2}\left(\mathrm{SO}_{4}\right)_{3}, \mathrm{Al}_{2} \mathrm{Cl}(\mathrm{OH})_{5}, \mathrm{FeSO}_{4}$ and $\mathrm{Ca}(\mathrm{OH})_{2}$ are mainly widely used coagulant at presents which distinguish emissions, efficiency, economics and waste water management [30]. Compared to the other chemicals, $\mathrm{Al}_{2} \mathrm{Cl}(\mathrm{OH})_{5}$ and $\mathrm{Al}_{2}\left(\mathrm{SO}_{4}\right)_{3}$ are being mostly used worldwide because of its lowcost and easily recoverable [31]. The coagulants and flocculants separate the stable parts suspended from POME which make POME is easy to filter with low pressure in the use of flux. Since there needs many chemicals used for POME treatment, common coagulant/flocculants, for example, chitosan and Moringa oleifera plants have been studied. Concerning economical and treatment performance, chitosan has exposed an auspicious option that it has better performance than $\mathrm{Al}_{2} \mathrm{Cl}(\mathrm{OH})_{5}$ and $\mathrm{Al}_{2}\left(\mathrm{SO}_{4}\right)_{3}$ [32].

The combined use of $\mathrm{Al}_{2}\left(\mathrm{SO}_{4}\right)_{3}$ and extracted natural seed gum has been done in the coagulation process for the treatment of raw POME but when only $\mathrm{Al}_{2}\left(\mathrm{SO}_{4}\right)_{3}$ is being used results are quite similar that is 81.58 and $48.22 \%$ for suspended solids reduction and COD reduction respectively [33]. Earlier, natural coagulant using like Moringa oleifera for the treatment procedure of POME, COD and suspended solids reduction has been recorded up to $52 \%$ and $95 \%$ respectively [34].

Adsorption treatment: An adsorption method is also being considered as a physicochemical treatment which is being used for the treatment of POME. Though it is not an exceptional treatment system for wastewater, this procedure is globally used because it has an environment-friendly operating system [35]. One of the most common adsorbents are chitosan which is mostly utilized in eliminating oil and grease from wastewater with heavy metals [36]. There are also other options for adsorbents like palm kernel fibre (PKF), wood sawdust, garlic peel. Mainly, for the extraction of residual oil, suspended solids and heavy metals, the adsorption treatment system is mostly being used.

Research has been conducted using chitosan as an adsorbent for POME treatment [37]. According to this study, Ahmad et al. found that using chitosan $97-99 \%$ of residual oil has been removed from POME. Though, the total suspended solid of the sample had previously removed for the oil treatment. Another experiment has been conducted by associating the use of absorption procedure with a combination of the magnetic field [38]. According to his experiment, the adsorbent was activated carbon. Remarkable changes have been noticed between single adsorption procedure with a combination of adsorption and magnetic field procedure. Percentage reduction in total suspended solid, COD and colour up to 61.11, 67.87 and $57.11 \%$, respectively have been found for single adsorption process where $98.455,98.99$ and $79.303 \%$, respectively found on a combination of adsorption and magnetic field process.

Membrane filtration treatment: Membrane filtration treatment is the method of separation, which is the most important and useful technique, which is used for POME treatment. The use of membrane filtration method has various benefits like less energy using, eco-friendly, simple operation and much space is not required. Membrane filtration method can be implemented widely on the industries, a process where it can allocate the recycling of waste streams and there is no need for highly skilled operators because the plant is fully automatic [39]. In 2014, an ultrafiltration membrane has been used for the treatment of POME [40]. Still, the treatment method is being 
combined as pretreatment with adsorption treatment. Flat sheet regenerated cellulose membrane, which has been used in this experiment.

To minimize the sludge particles in POME for avoiding fouling on the membrane surface, adsorption treatment has been applied before ultrafiltration of POME. A better quality of POME was attained by ultrafiltration membrane treatment and that's why it has been extensively used for the determination of water retrieval and distillation from both industrial and municipal waste. Membrane filtration treatment method can remove the massive amount of microorganism from wastewater [41]. Production of high-quality water is beneficial in this method in wastewater treatment by a simple and basic arrangement for the whole system [42]. Anyway, this method is not all the time perfect because membrane infiltration flux may turn down because of impurities which will be the reason for blockage in the membrane pores and will be the reason for shorter life prospect of the membrane. The cleaning process cost is also high. Table-4 is showing a comparison of various methods for POME treatment.

Advance oxidation process treatment: In this process, active hydroxyl ions $\left(\mathrm{OH}^{+}\right)$has been generated so that organic pollutants can be degraded [43]. It has been categorized into two types; photochemical and non-photo chemical process. The photochemical group is the resultant of photolysis by sunlight, $\mathrm{UV} / \mathrm{H}_{2} \mathrm{O}_{2}, \mathrm{UV} / \mathrm{TiO}_{2}$, Photo Fenton and the non-photo chemical group is the consequent of Fenton and ozonation method [44]. For wastewater treatment, Fenton's element has potential implement because it's a mixture of $\mathrm{H}_{2} \mathrm{O}_{2}$ with $\mathrm{Fe}^{2+}$ as catalyst [45]. Response Surface Methodology unit enhances the functional factors of Fenton procedure for the treated POME treatment before it is being released into the natural stream. Result for the decrease in colour and COD was found 97.36 and $91.11 \%$ correspondingly where $\mathrm{pH}$ value 3.5 and $30 \mathrm{~min}$ for HRT. Another experiment has also been conducted using UV responsive $\mathrm{ZnO}$ photo catalyst for POME treatment [46]. The result for COD reduction has been found up to $50 \%$ using $1.0 \mathrm{~g} / \mathrm{L}$ zinc oxide after $4 \mathrm{~h}$ of solar radiation.

Biogas production from anaerobic codigestion: $A C D D$ is not only an effective process for biogas yield but also wellused for environmental protection. Moreover, ACoD can develop system steadiness, nutrient stability and lessen greenhouse gas (GHG) radiations also other expensive treatment [47]. Due to direct use of organic constituents, nutritious inequity makes ACoD process difficult to produce biogas efficiently. Organic components must attain the nutritional prerequisites for bacteria development in the ACoD process for biogas yields. The carbon to nitrogen ratio is also accountable for the breakdown of organic constituents [48]. ACoD of waste water where nitrogen content is rich with biomass can alleviate the carbon to nitrogen proportion and develop progress rate of microbes [49]. Existing development of ACoD of various substrates and assessment of methane production is given in Table-5.

The factors disturbing ACoD is still indefinite for the modification of functioning constraints and optimization tactics. It is still needed more revisions for the system optimization and improvement of methane generation [50]. Additionally, the upheaval to developments might speed up by the

TABLE-4

COMPARISON OF VARIOUS POME TREATMENT METHODS

\begin{tabular}{|c|c|c|c|}
\hline Types & Advantages & Disadvantages & Ref. \\
\hline Aerobic & $\begin{array}{l}\text { BOD eviction effectiveness and effluent quality are } \\
\text { high, capable to reduce microbes from effluent, HRT } \\
\text { is not long, convenient to manage lethal effluent }\end{array}$ & $\begin{array}{l}\text { Aerobic method necessitates greater energy, } \\
\text { inappropriate land use, involves cyclic } \\
\text { monitoring }\end{array}$ & [92-94] \\
\hline Anaerobic & $\begin{array}{l}\text { Low-priced, easy design, steady and consistent } \\
\text { method, little working expenditure, improved mud } \\
\text { used as compost, less energy requisite }\end{array}$ & $\begin{array}{l}\text { Wide land use necessary, high mud growth, } \\
\text { HRT is high, need prolonged set up period }\end{array}$ & [95-97] \\
\hline $\begin{array}{l}\text { Coagulation or } \\
\text { flocculation }\end{array}$ & $\begin{array}{l}\text { Can quickly lessen OLR of POME, different } \\
\text { coagulant and flocculants readily existing, easy as } \\
\text { well as cost-effective }\end{array}$ & $\begin{array}{l}\text { Responsive to } \mathrm{pH} \text { adjust for creation of flocs } \\
\text { and act of coagulant, complicated process }\end{array}$ & [98-100] \\
\hline Adsorption & $\begin{array}{l}\text { Eco-friendly, little manufacture expenses, simple } \\
\text { method, high effectiveness }\end{array}$ & $\begin{array}{l}\text { Post treatment is needed, adsorbents are } \\
\text { difficult to be organized }\end{array}$ & [36] \\
\hline $\begin{array}{l}\text { Advanced oxidation } \\
\text { process (AOP) }\end{array}$ & $\begin{array}{l}\text { AOP respond with most microbes, able to degrade } \\
\text { highly insolent mix, simple to be useful }\end{array}$ & $\begin{array}{l}\text { High working expenditure, use of lot of } \\
\text { chemical, extreme mud production }\end{array}$ & {$[45,101]$} \\
\hline Membrane & $\begin{array}{l}\text { Tremendous effectiveness of effluence elimination, } \\
\text { less effort charge, small land area required }\end{array}$ & $\begin{array}{l}\text { High repairs charge, high stress necessary, } \\
\text { fouling, small life suspense }\end{array}$ & {$[102,103]$} \\
\hline
\end{tabular}

TABLE-5

CURRENT PROGRESS IN CODIGESTION OF DIFFERENT SUBSTRATES

\begin{tabular}{|c|c|c|}
\hline Substrate & Comparison of biogas yield & Ref. \\
\hline $\begin{array}{l}\text { Palm oil mill effluent and } \\
\text { cattle manure }\end{array}$ & $\begin{array}{l}\text { ACoD of these two substrates at carbon to nitrogen ratio of } 25: 1 \text { increased the biogas production of } \\
1875 \mathrm{~mL} / \mathrm{g} \mathrm{VS}_{\text {added }} \text { A Methane production rate of about } 61.13 \% \text { was also attained. }\end{array}$ & [86] \\
\hline $\begin{array}{l}\text { Palm oil mill effluent and } \\
\text { empty fruit brunches }\end{array}$ & $\begin{array}{l}\text { When POME was codigested with empty fruit branches (EFB), the maximum methane potential } \\
\text { was } 392 \mathrm{~mL} / \mathrm{g} \mathrm{VS} \text { added } \\
\text { corresponding to } 87.2 \mathrm{~m}^{3} \text { of mixed treated EFB with POME }(6.8: 1)\end{array}$ & [87] \\
\hline $\begin{array}{l}\text { Palm oil mill effluent and } \\
\text { sewage chemical sludge }\end{array}$ & $\begin{array}{l}\text { POME codigestion with sewage chemical sludge at mixing ratio of } 80: 20 \text {, gave the highest methane } \\
\text { yield of } 456 \mathrm{~mL} / \mathrm{g} \mathrm{VS}_{\text {added }} \text { keeping the carbon to nitrogen ratio 20:1 }\end{array}$ & [88] \\
\hline $\begin{array}{l}\text { Palm oil mill effluent and oil } \\
\text { palm fronds }\end{array}$ & $\begin{array}{l}\text { Codigestion of POME and oil palm fronds (OPF) with a mixing ratio of } 2: 1 \text { and at a carbon to } \\
\text { nitrogen ratio of } 40: 1 \text { produced methane about } 207 \mathrm{~mL} / \mathrm{g} \mathrm{VS} \text { added }\end{array}$ & [89] \\
\hline $\begin{array}{l}\text { Palm oil mill effluent and } \\
\text { decanter cake }\end{array}$ & POME with $10 \%$ Decanter Cake (DC) yields a methane production of $391 \mathrm{~mL} / \mathrm{g} \mathrm{VS}_{\text {added }}$ & [90] \\
\hline
\end{tabular}


use of precise modelling tactics in $\mathrm{ACoD}$ procedure [51]. The significant enrichment of biogas generation as an renewable energy can be attained in Malaysia. Fig. 1 is showing the flow chart for the ACoD for POME and cattle manure.

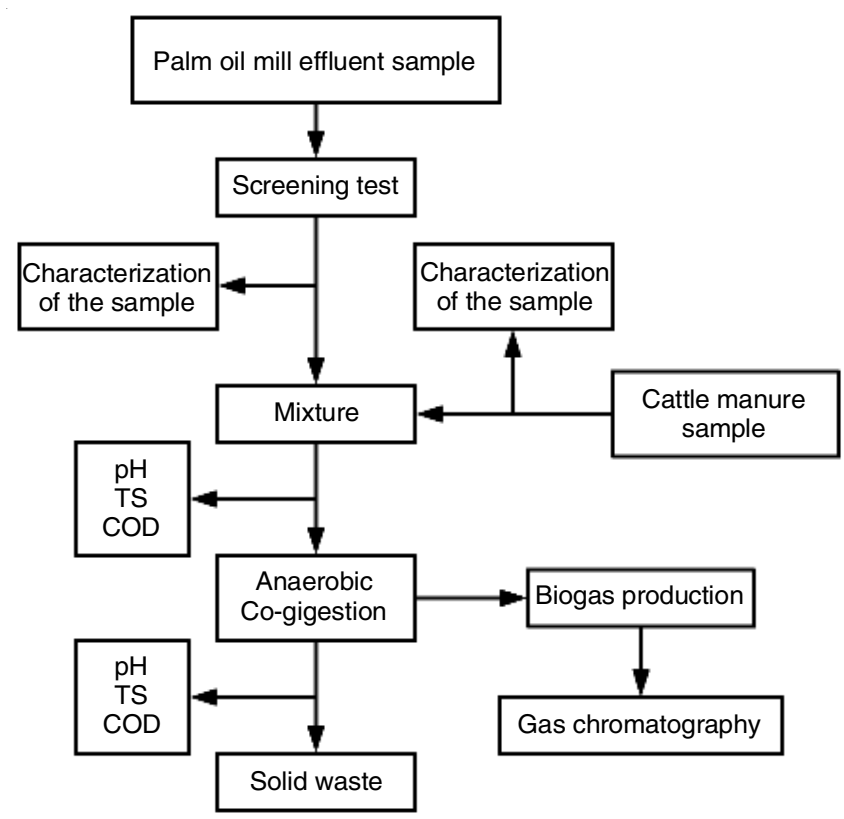

Fig. 1. Anaerobic codigestion process flow

Factors affecting ACoD: Methane, carbon dioxide and hydrogen gas are the main components of biogas from codigestion of POME and this production is influenced by numerous factors [52]. These factors have been classified as environmental and internal factors. However, improving the ACoD is a challenge because this technology is increasing the microbial action through sufficient mixing to make sure consistency of the environmental factors and also to increase the connection rate in between the substrates and cells [53].

Environmental factors: The factors which usually affect the internal operational condition of biogas production technique are environmental factors. These factors cause less biogas production and among them, temperature and $\mathrm{pH}$ are the major environmental factors.

pH: $\mathrm{pH}$ is an important parameter to evaluate the acid and alkaline character of wastewater and is a strength of POME for biogas generation. In the usual $\mathrm{ACoD}$ process, at every stage of biomethanization the several metabolic yields are sequentially converted in their resultant with no significant growth of transitional yields towards to turn down $\mathrm{pH}$. Methanogenic microbes are the main interrupter for the reduction in $\mathrm{pH}$. Internal and external $\mathrm{pH}$ is changed by microbes respond which is regulating their action and mixture of proteins accompanying by proton displacement, amino acid decadence and adjustment to acid or alkaline conditions [54]. Nonetheless, the acidity of the POME is naturally above the value by which optimal methane is produced. Differences in $\mathrm{pH}$ of the biodigester seriously affect numerous features of the multifaceted bacterial metabolism.

Usually, during biogas yield, neutral $\mathrm{pH}$ keeps stable the rate of methanogenesis. At $\mathrm{pH}$ range of 6.5 to 7.5 , methanogens increase the production of biogas [55]. So, it can be easily said that the amount of methane yield possibly will drop both at $\mathrm{pH}$ less than 6.5 and higher than 7.5. However, methane production instability because of $\mathrm{pH}$ increasing suggests that $\mathrm{pH}$ is not only liable to produce maximum methane from POME. Conversely, bicarbonates salts are vital for system stability to maintain volatile fatty acid (VFA) accumulation. Addition of sodium hydroxide can retain the $\mathrm{pH}$ of the system at 6.8-7.0 [56]. Sodium, potassium and lime can also be used in methanogens to maintain $\mathrm{pH}$ in biogas generation. However, these should be carried out progressively to avoid any conflict on the bacterial groups.

Temperature: Temperature is also an important factor during biogas production. Temperature assigns competence of methane yields due to its tendency to change with the change of hydrolysis and methanogenesis rates. Usually, the palm industry generates POME at $80-90{ }^{\circ} \mathrm{C}$ [57]. This temperature creates microbes with both mesophilic and thermophilic to work efficiently during treatment [10]. The high amount of biogas production can be found at a high temperature like at thermophilic temperature $\left(55^{\circ} \mathrm{C}\right)$ concerning mesophilic temperature $\left(37^{\circ} \mathrm{C}\right)$. Theoretically, mesophilic microbes are more dynamic, strong and able to survive with the discrepancy in ecological situations. Temperature has an important role in organic loading rate (OLR) and HRT. More biogas yields are possible in high OLR and short HRT. Therefore, using suitable insulation technology, more biogas can be produced in a thermophilic condition.

Internal factors: There are several internal factors, which affect biogas production in $\mathrm{ACoD}$ process. These factors include nutrients composition, OLR, HRT, microbial activity, inhibitory materials, pressure, mixing conditions, chemical equilibrium, etc.

Nutrients composition: By microbial breakdown of POME, biogas is produced. Various macro and micro nutrients are required to function successfully for biogas production. Sodium, potassium, calcium, magnesium, iron, cadmium, nitrogen and chromium are nutrient contents in POME. Even some minerals originated from POME may be poisonous in microbes using in biogas production. These poisonous elements are formed from leaching procedure, which decreases biogas production rate. Precipitation may increase the amount of POME at the time of processing which will affect nutrient level as well as inhibitory materials.

Hydraulic retention time: It is a determination of how much time a substrate exists in a bioreactor. System failure generally occurs because of short HRT [28]. It has been called the significant bacterial community of the bioreactor growth rate; even this procedure results in the high volume of biomethane production [58]. Three days HRT can make $71.9 \%$ biogas generation rate [59]. Lengthy digestion, effluent nature, $\mathrm{pH}$, OLR in increasing metabolic move by HRT [60]. Moreover, short HRT produces a higher amount of biogas but less efficient organic matter degradation.

Organic loading rate: It is the amount of a biological substance that is treated by anaerobic digester in a time duration. OLR is habitually related with HRT. High OLR value can be found at short HRT in stable organic substrates. EGSB 
overloading may cause poor biomass settlement, which could be washed off by the wastes [61]. The more the OLR increases, the more the biogas generation rate is increased. Although extra OLR for organic overloading habitually consequences an increase of $\mathrm{pH}$ which is harmful to methanogens may reduce methane production [62]. Mostly HRT, as well as OLR optimization, lean on the style of arrangement. Higher methane production can be generated at lower organic loading and higher retention time in an anaerobic digester.

Microbial activities: The role of microbial activities is often given in biogas production. Biogas production is a difficult procedure, which involves diverse procedures which are hydrolysis, acidogenesis, acetogenesis and methanogenesis with different kinds of microbes. Isolated microbes may lead to higher biogas production from POME. There is some limitation to work on the bacterial content of POME. The few available bacterial content ranges are $10^{5}-10^{6} \mathrm{CFU} / \mathrm{mL}$. Methanogenesis also plays a vital role in methane generation because of being a key aspect in the anaerobic digestion. Introducing more methanogens into the medium can optimize the microbial elements. Compared to other microbes, which are stated in POME, low methanogens play a significant role in hydroelectricity, acidogenesis and acetogenesis.

Inhibitory materials: The existence of inhibitory materials is harmful to the system, which may decrease the rate of biogas generation without substantial COD decreasing. It also causes failure of bacterial groups for adaptation. Because of their metabolic affinities, adaptation can make reposition or reorganization of microbes to exceed metabolic shock, which is produced by the presence of inhibitory materials. Light and heavy metal ions and the organic compound can cause inhibition during $\mathrm{ACoD}$ of POME in biogas generation. Sodium, potassium, calcium and magnesium are the light metal ions. In this case, sufficient light metal ions are essential for microbial growth stimulation because high ions content may support inhibition and decrease development. Potassium occurs in large concentration in POME [63]. Moreover, heavy metals can increase the intensification of microflora even if it is difficult for biodegradability and may be possible to accumulate toxicity in the anaerobic reactor. The toxicity of heavy metals can neutralize extensively of enzyme function and structures [19]. Biological components of POME also take inhibitory latent during $\mathrm{ACoD}$ to produce biogas.

Pressure: During ACoD procedure, high pressure produced in the biogas reactor may affect the methane production rate. There are barophilic microbes present in POME. The microbial and chemical compatibility challenge may be encountered on the system at high pressure if the produced methane is not supply immediately into usage. Methane production can be low because of low methanogenic microbes' inhabitants in POME. Total pressure, which arises during methane yields badly affects microbes if the reactor outside gas load is superior to the reactor inside gas load. The biogas and air inside the reactor may explode if the air is pulled by negative pressure. If this explosion happens, the bacterial properties of the POME are destroyed by the oxygen and production of methane will end. The solution to this problem is using the methane instantly after being produced.
Mixing condition: Appropriate mixing helps in dilution of materials, which are inhibitory and ensure steadiness of allowing ecological state for optimum methane production [64]. During ACoD of POME, total biogas yield is affected because of variation of $\mathrm{pH}$ or temperature in the reactor. Hence, for maximum biogas production, mixing plays a vital role and mixing should be moderate since inadequate mixing disturbs methanogenesis originated in POME.

Chemical balance: There are three procedures which impact the chemical balance of biogas yield, i.e. hydrolysis relating the interruption of multifaceted polymers into monomers of POME, the transformation of volatile fatty acid to acetate, $\mathrm{H}_{2}$ gas and $\mathrm{CO}_{2}$ and the use of biogas yield. In hydrolysis, higher energy is required and the procedure is timeconsuming. It reflects as the dynamic strength of methane yield from POME. Methane yield from volatile fatty acid is generated by the actions of acetogenic and acetoclastic methanogens. Thermodynamically, codigestion procedure is preferred when the pressure is low for hydrogen. The restrictive step for biogas production rate is methanogenesis [65].

Carbon to nitrogen ratio: Carbon to nitrogen $(\mathrm{C}: \mathrm{N})$ proportion for macrobiotic substances affects whole codigestion procedure [66]. The digesting medium is having optimum C:N proportion supplies adequate supplements for microbes to maximize methane yields. Consequently, substrates having lower $\mathrm{C}$ : $\mathrm{N}$ proportion provides advanced ammonia concentrations and encumbers microbes development. But, if $\mathrm{C}: \mathrm{N}$ proportion value is more than the optimum value in the anaerobic digestion, a huge quantity of volatile fatty acid is formed. So, suitable $\mathrm{C}: \mathrm{N}$ proportion plays a vital role in $\mathrm{ACoD}$ for methane production. The important constraint of cattle manure is the shortage of nutrient compositions, mostly lower $\mathrm{C}: \mathrm{N}$ proportion reduces microbial action. Organic wastes are usually rich in lignocelluloses-type defiant materials. So, especial pretreatments are necessary to use such wastes in lower HRT in the anaerobic digestion [67]. In the $\mathrm{ACoD}$ procedure, co-substrates addition maintains the $\mathrm{C}: \mathrm{N}$ ratio in anaerobic digestion reactors [68]. The optimum C:N proportion of each substance obtained from various anaerobic digestion procedure is different. The value of C:N proportion of 20 to 30 makes the anaerobic digestion procedure steadier.

Strategies for improving biogas production: Several improving strategies and efficiency had been studied for improving the methane production from POME by ACoD. However, no strategies can be related directly with each other because of effectiveness and distinct operational condition. $\mathrm{ACoD}$ is a procedure in which the result is easily regulated by many aspects, i.e. start-up efficiency, functional condition and bioreactor design. Various strategies for improving biogas production are defined below.

\section{POME pretreatment}

POME deoiling: Oil and grease are the substances present in POME, which creates a problem during $\mathrm{ACoD}$ because these are the inhibitor in development of long chain fatty acid (LCFA). The metabolites of the lipids hydrolysis are called long chain fatty acids which growth will lessen the methane yield [69]. It is required to do deoiling of the POME before 
nourishing into the bioreactor to overcome this encounter [61]. By this way a better methane production about $126.4 \%$ is possible. This procedure removes the waste lipids that are the component for potential methane generation rather than carbohydrates and proteins [69].

POME sedimentation: As a pretreatment, POME sedimentation is another approach to increase the ACoD performance. Pre-settled POME, which nourished in the UASFF reactor had attained optimum methane production of $0.344 \mathrm{~L}$ $\mathrm{CH}_{4} \cdot \mathrm{gCOD}_{\text {removed }^{-1}}$ [70]. By this way, the theoretical methane production had attained about $0.35 \mathrm{~L} \mathrm{CH}_{4} \cdot \mathrm{gCOD}_{\text {removed }^{-1}}$. By removing the non-digestible suspended dense portion, this improvement is possible that will decrease the effectiveness of digestion operation by assigning in the bioreactor. However, the enhancement of methane production by this technology is not remarkable when various bioreactor design and operation situations are functional [71].

POME pre-hydrolysis: In the $\mathrm{ACoD}$ procedure, hydrolysis is considered as the restrictive rate step [72]. Hence, POME pre-hydrolysis method is supposed to improve the biogas production efficiently. The dose of $\mathrm{O}_{3}$ of $0.4 \mathrm{~g} \mathrm{~L}^{-1}$ is stated importantly to boost the biogas production from POME by $92.5 \%$. This upgrading is happened because of improved toxicants lessening and biodegradability of POME. Additionally, to solubilize COD, the combination of pre-hydrolysis with thermal-alkaline pretreatment is also an effective technology and so increase the biogas production of POME from ACoD [73].

Inorganic additive supplementation: Supplementation of inorganic additives such as calcium oxide-cement oven dust, red mud-iron and chitosan for codigestion of POME is mostly used to enhance biomass retaining in the reactor. The activity of these additives is to enhance the bacterial granulation procedure, lessen the biomass washout and then expand the biogas yield. When the concentration of these additives is optimal, then it is considered as the overdose and that will cause adverse effects.

Biological additive supplementation: The biological additive supplementation technique in $\mathrm{ACoD}$ system will normally require adequate acclimatization and start-up period to make sure the unfamiliar bacterial group supplementation which can adjust to the new environment and rise significantly. The similar result has been found when the rumen fluid was added for ACoD of POME [74]. The methanogens presence in the rumen fluid is considered as the kind of methanobrevibacter. The reactors with rumen fluid additive supplementation have made better COD removal and biogas generation after the acclimation and set up phase.

Bioreactor modification: There are several anaerobic bioreactors for POME treatment such as a packed-bed reactor, expended-bed reactor, fluidized-bed reactor and immobilizedcell bioreactor. The present treatment process of POME has been modernized, evaluated and revised by Ahmed et al. [35]. All these bioreactors are established for treatment effectiveness and expected methane yield in a research laboratory. The most satisfactory bioreactor for POME treatment in commercialized purposes is continuous stirred tank reactor (CSTR). The familiar benefits of continuous stirred tank reactor are less financing and operational charge, the easy setup also stress-free to regulate [35]. The novelty in the design of anaerobic bioreactor system, especially for improving biogas yield from POME is limited. Some modifications in these bioreactors can contribute to the performance improvement of the anaerobic digestion.

Carrier anaerobic baffled reactor: In an ASBR, a packed bed was added which has hollow in the centre [75]. A deflector was fixed in a continuous stirred tank reactor [76]. Both are used for improving the retention of biomass. These two bioreactors have attained the biogas yield of 36.76 and 36.13 $\mathrm{L}$, respectively on a daily basis. The carrier anaerobic baffled reactor can also be modified by the addition of the polymeric media [77]. This bioreactor is considered as the carrier anaerobic baffled reactor and has attained a methane production of $0.25 \mathrm{~L} \mathrm{CH}_{4} \cdot \mathrm{gCOD}_{\text {removed }^{-1}}$. The fixing of sludge or biomass sedimentation, as well as recycling method, is one of the appropriate reforms to intensify biomass maintenance in carrier anaerobic baffled reactor [78].

Solar assisted bioreactor (SABr): Solar energy is utilized for heating necessities of bio-organic waste digesters at little functioning cost. The necessity of heating anaerobic digesters is greatly related to increase biogas yield rate and decrease retention time. It can be avoided by using solar bioreactor for the reactors, which uses electric and diesel heating and produce biogas, which minimizes the cost of renewable energy production. The solar panel design provides to the bioreactor with ample necessities. The temperature is enough to provide the heating necessities of the bio reactor. Previously study showed that mesophilic $\left(37^{\circ} \mathrm{C}\right)$ and thermophilic $\left(55^{\circ} \mathrm{C}\right)$ condition are reasonable working temperature for anaerobic digestion process. Heating the anaerobic digesters can be exclusively attained from a solar energy system and can produce biogas all through the year. Heating anaerobic digesters by solar energy are proving as an exceptional approach for production of renewable energy. By this solar collector panel, the theoretical efficiency is measured above $60 \%$ [79]. The significance of this controlled solar bioreactor is to obtain the required temperature of the system within $1 \mathrm{~h}$ and then can be properly maintained.

Feasibility analysis: $\mathrm{ACoD}$ is considering now as high comprehensive growing prospective. The recent development of increasing biogas yields worldwide tends to last longer in future because of increasing concerns about GHGe and poor aquatic quality. New rules and incentives are favouring $\mathrm{ACoD}$ and other renewable energy technologies and waste management replacements. By the perspectives of the environment and economic benefits, this technology is now increasing awareness, which will allow the beginning of strategies and incentives all over the world. At present, setting up of domestic digesters is expected to keep growing, especially in Malaysia, with high potential for this system. Many areas where there is no electricity and that's why they have to depend on wood and fuels are the right place to execute this system because it has an exceptional probability to provide renewable energy while alleviating waste materials and developing livelihood standard of farmers. Financial supports from the government and various private companies are required to execute this and this will be probably the key driver. The main things for this 
system to get proper economic and environmental benefits for the long run are: fixing digesters having a good condition which needs less maintenance and renovation cost, stay operative for a lengthier period, convenient in maintenance and troubleshooting of this system. The main obstacle for the development of ACoD technology is the appropriate supervision of the greater amount of biogas production because making its carriage and storage is relatively cost. Combined heat and power unit usage for biogas utilization will be the greatest cost-effective alternate in the near future. Technological advancement in biogas promotion procedures is an essential and efficient alteration of transportation fuels and other chemicals.

Economic feasibility of the construction of a biogas plant for ACOD of POME and cattle manure: A preliminary data set is required for a commercial feasibility study of a plant. About $100,000 \mathrm{~m}^{3}$ substrate/year is calculated to be treated considering the quantity of POME, cattle manure and the dilution applied (1:5) (20,000 $\mathrm{m}^{3} \mathrm{POME}$ without dilution/year, 2,000 tons cattle manure/year and for dilution $90,000 \mathrm{~m}^{3}$ water/ year) [80]. The production of biogas per $\mathrm{m}^{3}$ substrate is about $13 \mathrm{~m}^{3}$ and the methane generation per $\mathrm{m}^{3}$ substrate is about $6.85 \mathrm{~m}^{3}$ [81]. Considering the methane's calorific value is 9.7 $\mathrm{kWh} / \mathrm{m}^{3} \mathrm{CH}_{4}$, thermal energy is generating during the anaerobic digestion of these substrates is about $7.55 \mathrm{GWh} /$ year.

A biomethanization plant requires a stirred container digester having an operating volume of about $17,000 \mathrm{~m}^{3}$, whose height is $15 \mathrm{~m}$ and diameter is $15 \mathrm{~m}$ to produce this amount of energy where HRT is assumed 40 days. The plant needs a biogas storage container whose volume is $2700 \mathrm{~m}^{3}$. The POME treatment will be done in a stagnant vessel flowing horizontally having a volume of $350 \mathrm{~m}^{3}$ where width $10 \mathrm{~m}$, length $28 \mathrm{~m}$ and height $1.25 \mathrm{~m}$. The plant construction cost has been projected approximately $1,860,300$ USD (Table-6). The effectiveness of the container usually heats the POME dedicated to making sure thermal steadiness in the reactor at mesophilic temperature $\left(37{ }^{\circ} \mathrm{C}\right)$ has been accounted. About $22 \%$ losses are usually happened by the upper crust of the reactor and more, $5 \%$ losses have been considered by pipes and plant insulation. This produces energy of the biogas plant of $2.86 \mathrm{GWh} /$ year. Thus, the rest of the produced energy for water pumping is $4.52 \mathrm{GWh} /$ year. The heat adjustment refers to the standard yearly value of temperature.

The plant is constructed in a total of 20,500 hectares land area where around $25 \%$ is used for collection and storage of cattle manure. The net required energy for the plant is about 19.2 GWh/year considering $10 \%$ loss from the roughness of pipes. Also, the plant energy system works an average of 3,250 h/year with $78 \%$ efficiency. So, $3.68 \mathrm{GWh} /$ year will be required energy for the plant, which is $78 \%$ of the $4.72 \mathrm{GWh} /$ year. 19.2 GWh/year are required energy of the plant and the total energy will be about $20 \%$ of the yearly energy necessities from the biogas plant.

It is distinguished that 30 pumps are selected which are fueled by biogas. The nominal power of these pumps is $50 \mathrm{~kW}$ and costs 2,730 USD per pump and thus the total cost of motor pumps is 81,900 USD. The transportation area is considered around $20 \mathrm{~km}$. In Table-6, an economic feasibility analysis for this biogas plant has been shown. The plant needs to make payment to the electricity energy supplying company is 0.213 USD/kWh. For example, the yearly profit because of savings in energy produced by the pumps where electric power is used replaced with motor pumps where the fuels came from biogas generated in this biogas plant will be about 519,480 USD/ year. Additionally, the economic variables such as internal rate of return (IRR), the net present value (NPV) and payback time (PBT) analysis are showing 5,768,393 USD, $29.7 \%$ and four years respectively. This analysis explains magnified expenses and sizes for apparatus. So, the outcome existing in this manuscript may be considered established.

TABLE-6

ECONOMIC STUDY OF AEROBIC-ANAEROBIC TREATMENT OF POME AND CATTLE MANURE

\begin{tabular}{|c|c|c|}
\hline Preliminary data & Substrate to treat $\left(\mathrm{m}^{3} /\right.$ year $)$ & 100,000 \\
\hline & Methane yield ( $\mathrm{m}^{3}$ methane $/ \mathrm{m}^{3}$ substrate) & 6.85 \\
\hline \multirow[t]{3}{*}{ Energy requirement } & $\mathrm{kWh}$ cost $(\mathrm{US} \$ / \mathrm{kWh})$ & 0.213 \\
\hline & Energy requirement for plant (GWh/year) & 19.2 \\
\hline & Energy contribution of the anaerobic digestion plant $(\mathrm{GWh} /$ year) & 2.86 \\
\hline \multirow[t]{5}{*}{ Production } & Energy production $(\mathrm{GWh} /$ year) & 7.55 \\
\hline & Useful energy for plant (GWh/year) & 3.68 \\
\hline & Installed power $(\mathrm{kW})$ & 1420 \\
\hline & Useful power $(\mathrm{kW})$ & 1094 \\
\hline & Contribution to total energy requirement $(\%)$ & 18.96 \\
\hline \multirow[t]{3}{*}{ Overhead cost of the anaerobic digestion plant } & Total cost (US\$) & $1,860,300$ \\
\hline & Installation cost (US\$) & $1,778,400$ \\
\hline & Motor-pumps cost (US\$) & 81,900 \\
\hline \multirow[t]{6}{*}{ Yearly cost } & Costs derived from operation and maintenance (US\$) & 60,255 \\
\hline & POME transport cost (US\$) & 91,494 \\
\hline & Loan (US\$) & 183,105 \\
\hline & Electricity requirement cost in the plant (US\$) & 167,404 \\
\hline & Dilution water pumping cost (US\$) & 3,709 \\
\hline & Yearly total cost (US\$) & 505,967 \\
\hline Yearly income & Savings in electricity, yearly income (US\$) & $1,026,324$ \\
\hline Yearly benefits & Yearly profits (US\$) & 520,299 \\
\hline \multirow[t]{3}{*}{ Economic ratios } & Payback time (years) & 3.93 \\
\hline & Net present value (US\$) & $5,768,393$ \\
\hline & Internal rate of return $(\%)$ & 29.7 \\
\hline
\end{tabular}


Ecological advantages: There are numerous environmental benefits of codigestion such as treatment of POME, renewable energy production, less energy requirement, total heating potential and reduction of using inorganic fertilizer. These benefits are related to advanced environmental radiations such as nutrient leakage, methanogenic discharges from biodegradation and ammonia vaporization. In this regard, unwell accomplished animal compost leads to considerable environmental discharges where the animal production is liable for $18 \%$, anthropogenic $\mathrm{CH}_{4}$ is $37 \%$, anthropogenic nitrous oxide is $65 \%$ and anthropogenic ammonia releases is $64 \%$ [82]. However, it is necessary to get meaningful results for the environmental influences to install and operate biogas plants and proper usage of digestion. At present, there are many biogas plants around the world because of economic supports to install biogas plants [83]. All these biogas plants produce greater amount of biogas, which should have used in an environmental friendly way or else it will cause environmental damage because of nutrient overflow [84]. At the time of biogas production from biogas plants, methane and carbon dioxide discharges because of leakage, which contributes to overall greenhouse gas [85].

Biogas is used as transport gases or combusted in internal combustion. The welfare of ACoD systems is that it could help palm oil industry to expand systems competence to classify appropriate methods for a large-scale application, which can reduce environmental effects by reducing waste and using fossil fuel for electricity generation and replacement of chemical composts. The more the organic materials are present in POME, the more appropriate the ACoD process will be. Less water content and a high amount of energy can affect the environment much.

Other environmental advantages of ACoD system are generation of electricity, the reduction of odour from the compost, reduction of removing trees because of reduced fuelwood ingesting and reduction of health impacts because less inside house smoke formation compared to cooking with fuelwood. There are very few actions are recommended to reduce radiations and environmental influence; during combined heat and power outages global warming potential is reduced by using flash to lessen $\mathrm{CH}_{4}$ radiations to the air, reduction of the biogas outflows from the digester, appropriate storing and organization of great amount of digestion lessen global warming potential and eutrophication. External electricity demand of this system can be condensed by using the biogas yield.

Concluding remarks and future perspectives: There are several economic benefits of this $\mathrm{ACoD}$ such as reduction in expenditures in waste management by using the renewable energy produced as biogas, electricity and heat, making revenue by retailing energy and reduction in fertilizer participation to improve soil fertility. All over the world, ACoD systems have differences in feedstock types and arrangements, reactor gauge, working situations, financial inducements and prospective usage of yields. The energy requirement of controlling the digester temperature differs significantly based on geographical location. The supervision of this type of ACoD plant share assets such as manpower and devices that contribute optimistic finances of this system. The main challenge for this
ACoD system is to keep working all over the year at maximum efficiency. Transportation of raw materials and products is also significant for the financial and ecological feasibility as distance transport will enhance the biogas production costs and related radiations. So, this system needs evaluation for their financial feasibility considering the inconsistency of all precise features.

Because of increasing natural energy resources cost and risk of affecting the environment, energy resources demand is growing up which are sustainable and providing electricity. Though the global population is increasing, the global energy supply has finished in recent times. So, the world needs energy like renewable energy resources. In Malaysia, POME has been introduced as one of the best rising renewable energy resources. Though biogas production is at toddler phase, Malaysia is presently drumming the assets for renewable energy production. ACoD has been implemented globally in domestic digesters in village areas of unindustrialized countries to industrialized countries. Industrial developments approaching waste management as well as the production of biogas will boost the economics of a country and many industries will grow up upon this technology. After the biogas production from $\mathrm{ACoD}$ of POME and cattle manure, large volume water is released among, which $60 \%$ waster is clean and suspended solids removed which can be utilized in any usual, agronomic and industrial use.

\section{ACKNOWLEDGEMENTS}

The authors grateful to the Faculty of Engineering Technology (FTeK) of Universiti Malaysia Pahang (UMP) for their support and this study was fully financed by RDU-1603136 grant.

\section{CONFLICT OF INTEREST}

The authors declare that there is no conflict of interests regarding the publication of this article.

\section{REFERENCES}

1. I. Mukherjee and B.K. Sovacool, Renew. Sustain. Ener. Rev., 37, 1 (2014); https://doi.org/10.1016/j.rser.2014.05.001.

2. J. Potts, M. Lynch, A. Wilkings, G.A. Huppé, M. Cunningham and V.A. Voora, The State of Sustainability Initiatives Review 2014: Standards and the Green Economy, International Institute for Sustainable Development (2014)

3. M.J.I. Zahari, A. Baharum, F.H. Anuar and R. Othaman, Environ. Technol. Innov., 9, 169 (2018);

https://doi.org/10.1016/j.eti.2017.11.003.

4. A. Latif Ahmad, S. Ismail and S. Bhatia, Desalination, 157, 87 (2003); https://doi.org/10.1016/S0011-9164(03)00387-4.

5. S. Vijaya, A. Ma, Y. Choo and N. Nik Meriam, J. Oil Palm Res., 20, 484 (2008).

6. T. Forster-Carneiro, M. Pérez and L.I. Romero, Bioresour. Technol., 99, 6994 (2008); https://doi.org/10.1016/j.biortech.2008.01.018

7. M.N.I. Siddique and Z.A. Wahid, J. Clean. Prod., 194, 359 (2018); https://doi.org/10.1016/j.jclepro.2018.05.155.

8. Z. Liu, C. Zhang, Y. Lu, X. Wu, L. Wang, L. Wang, B. Han and X.-H. Xing, Bioresour. Technol., 135, 292 (2013); https://doi.org/10.1016/j.biortech.2012.10.027.

9. A. Hniman, S. O-Thong and P. Prasertsan, Int. J. Hydrogen Energy, 36, 8785 (2011); https://doi.org/10.1016/j.ijhydene.2010.09.067.

10. P.E. Poh and M.F. Chong, Bioresour. Technol., 100, 1 (2009); https://doi.org/10.1016/j.biortech.2008.06.022. 
11. D. Poggio, M. Walker, W. Nimmo, L. Ma and M. Pourkashanian, Waste Manag., 53, 40 (2016); https://doi.org/10.1016/j.wasman.2016.04.024.

12. A. Abdel-Galil, M.A. Elnono, M.M. Mostafa and M.F. Mohamed, Misr J. Agric. Eng., 25, 1438 (2008).

13. Y. Zhang, L. Yan, X. Qiao, L. Chi, X. Niu, Z. Mei and Z. Zhang, J. Environ. Sci. (China), 20, 558 (2008); https://doi.org/10.1016/S1001-0742(08)62094-X.

14. R. Borja and C.J. Banks, J. Chem. Technol. Biotechnol., 61, 103 (1994); https://doi.org/10.1002/jctb.280610204.

15. S.J. Santosa, CLEAN-Soil, Air Water, 36, 453 (2008); https://doi.org/10.1002/clen.200800039.

16. G. Singh, L.K. Huan, T. Leng and D.L. Kow, Oil Palm and the Environment: A Malaysian Perspective, Malaysian Oil Palm Growers' Council, Kuala Lumpur, Malaysia (1999).

17. K. Sundram, R. Sambanthamurthi and Y.-A. Tan, Asia Pac. J. Clin. Nutr., 12, 355 (2003).

18. K. Lo, N. Bulley, P. Liao and A. Whitehead, Agric. Wastes, 8, 155 (1983); https://doi.org/10.1016/0141-4607(83)90114-2.

19. Y. Chen, J.J. Cheng and K.S. Creamer, Bioresour. Technol., 99, 4044 (2008); https://doi.org/10.1016/j.biortech.2007.01.057.

20. L. Appels, J. Baeyens, J. Degrève and R. Dewil, Pror. Energy Combust. Sci., 34, 755 (2008); https://doi.org/10.1016/j.pecs.2008.06.002.

21. F. Chin, FAO-University of Sam Rapulangi, Manado, North Sulawesi, Indonesia (2001).

22. M. Habib, F. Yusoff, S. Phang, K. Ang and S. Mohamed, Aquaculture, 158, 95 (1997); https://doi.org/10.1016/S0044-8486(97)00176-2.

23. A.R. Khalid and W.A.W. Mustafa, Environmentalist, 12, 277 (1992); https://doi.org/10.1007/BF01267698.

24. P.F. Rupani, R.P. Singh, M.H. Ibrahim and N. Esa, World Appl. Sci. J., 11, 70 (2010).

25. T.K. Hwang, S.M. Ong, C.C. Seow and H.K. Tan, The Planter, 54, 749 (1978).

26. A. Salihu and M.Z. Alam, J. Appl. Sci. Res., 8, 466 (2012).

27. B. Rincón, F. Raposo, J.R. Domínguez, F. Millán, A.M. Jiménez, A. Martín and R. Borja, Int. Biodeter. Biodegrad., 57, 114 (2006); https://doi.org/10.1016/j.ibiod.2005.12.004

28. M.N.I. Siddique, M.S.A. Munaim and Z. Ab. Wahid, J. Clean. Prod., 133, 504 (2016); https://doi.org/10.1016/j.jclepro.2016.05.183.

29. J. Chotwattanasak and U. Puetpaiboon, J. Sustain. Energy Environ., 2, 133 (2011).

30. J.K. Edzwald, Water Sci. Technol., 27, 21 (1993); https://doi.org/10.2166/wst.1993.0261.

31. J. Keeley, A.D. Smith, S.J. Judd and P. Jarvis, Sep. Purif. Technol., 131, 69 (2014); https://doi.org/10.1016/j.seppur.2014.04.033.

32. A.L. Ahmad, S. Sumathi and B.H. Hameed, Chem. Eng. J., 118, 99 (2006); https://doi.org/10.1016/j.cej.2006.02.001.

33. K.P.Y. Shak and T.Y. Wu, Ind. Crop Prot., 76, 1169 (2015); https://doi.org/10.1016/j.indcrop.2015.07.072.

34. S. Bhatia, Z. Othman and A.L. Ahmad, J. Hazard. Mater., 145, 120 (2007); https://doi.org/10.1016/j.jhazmat.2006.11.003.

35. Y. Ahmed, Z. Yaakob, P. Akhtar and K. Sopian, Renew. Sustain. Ener. Rev., 42, 1260 (2015); https://doi.org/10.1016/j.rser.2014.10.073.

36. M.A. Shavandi, Z. Haddadian, M.H.S. Ismail and N. Abdullah, $J$. Taiwan Inst. Chem. Eng., 43, 934 (2012); https://doi.org/10.1016/j.jtice.2012.07.001.

37. A.L. Ahmad, S. Ismail and S. Bhatia, Chem. Eng. Sci., 60, 5385 (2005); https://doi.org/10.1016/j.ces.2005.04.021.

38. R.R. Mohammed, M.R. Ketabchi and G. McKay, Chem. Eng. J., 243, 31 (2014); https://doi.org/10.1016/j.cej.2013.12.084

39. M. Cheryan and N. Rajagopalan, J. Membr. Sci., 151, 13 (1998); https://doi.org/10.1016/S0376-7388(98)00190-2.

40. N.S. Azmi and K.F.M. Yunos, Agric. Agric. Sci. Procedia, 2, 257 (2014); https://doi.org/10.1016/j.aaspro.2014.11.037.

41. S. Judd, Principles and Applications of Membrane Bioreactors for Water and Wastewater Treatment, Butterworth-Heinemann, edn 2 (2010).
42. A. Ahmad, S. Sumathi and B. Hameed, Water Res., 39, 2483 (2005); https://doi.org/10.1016/j.watres.2005.03.035.

43. S. Chou, C. Huang and Y.-H. Huang, Chemo., 39, 1997 (1999); https://doi.org/10.1016/S0045-6535(99)00089-2.

44. I. Carra, J.A. Sánchez Pérez, S. Malato, O. Autin, B. Jefferson and P. Jarvis, J. Chem. Technol. Biotechnol., 91, 72 (2016); https://doi.org/10.1002/jctb.4577.

45. M.O. Saeed, K. Azizli, M.H. Isa and M.J. Bashir, J. Water Protect. Eng., 8, e7 (2015); https://doi.org/10.1016/i.jwpe.2014.11.001.

46. K.H. Ng and C.K. Cheng, Chem. Eng. J., 300, 127 (2016); https://doi.org/10.1016/j.cej.2016.04.105.

47. C.A. Henard, H.K. Smith and M.T. Guarnieri, Metab. Eng., 41, 152 (2017); https://doi.org/10.1016/j.ymben.2017.03.007.

48. M.N.I. Siddique, M.S. Abdul Munaim and A.W. Zularisam, J. Clean. Prod., 106, 380 (2015); https://doi.org/10.1016/i.jclepro.2014.08.003.

49. N.I. Siddique, M.S.A. Munaim and Z.A. Wahid, J. Clean. Prod., 91, 229 (2015); https://doi.org/10.1016/j.jclepro.2014.12.036.

50. K. Hagos, J. Zong, D. Li, C. Liu and X. Lu, Renew. Sustain. Ener. Rev., 76, 1485 (2017) https://doi.org/10.1016/j.rser.2016.11.184.

51. S. Xie, F.I. Hai, X. Zhan, W. Guo, H.H. Ngo, W.E. Price and L.D. Nghiem, Bioresour. Technol., 222, 498 (2016); https://doi.org/10.1016/j.biortech.2016.10.015.

52. M.K. Lam and K.T. Lee, Biotechnol. Adv., 29, 124 (2011); https://doi.org/10.1016/j.biotechadv.2010.10.001.

53. M.N.I. Siddique, M. Sakinah Abd Munaim and A.W. Zularisam, $J$. Ind. Eng. Chem., 20, 331 (2014); https://doi.org/10.1016/j.jiec.2013.03.030.

54. E.R. Olson, Mol. Microbiol.., 8, 5 (1993); https://doi.org/10.1111/j.1365-2958.1993.tb01198.x.

55. S.M. Stronach, T. Rudd and J.N. Lester, Anaerobic Digestion Processes in Industrial Wastewater Treatment, Springer (1986).

56. N. Abdurahman, N. Azhari and Y. Rosli, Int. Persp. Water Quality Management Pollution Conference (2013).

57. S.E. Hosseini and M.A. Wahid, J. Air Waste Manag. Assoc., 65, 773 (2015); https://doi.org/10.1080/10962247.2013.873092.

58. U. Zaher, R. Li, U. Jeppsson, J.-P. Steyer and S. Chen, Water Res., 43, 2717 (2009); https://doi.org/10.1016/j.watres.2009.03.018.

59. N.I. Siddique and Z.A. Wahid, J. Environ. Sci. Technol., 5, 155 (2012); https://doi.org/10.3923/jest.2012.155.167.

60. M.N.I. Siddique, M.S.A. Munaim and Z.B.A. Wahid, J. Clean. Prod., 145, 303 (2017); https://doi.org/10.1016/i.jclepro.2017.01.061

61. M.N.I. Siddique, M.S.A. Munaim and A.W. Zularisam, J. Taiwan Inst. Chem. Eng., 58, 451 (2016); https://doi.org/10.1016/j.jtice.2015.06.038.

62. T. Mechichi and S. Sayadi, Process Biochem., 40, 139 (2005); https://doi.org/10.1016/j.procbio.2003.11.050.

63. M.K.C. Sridhar and O.O. AdeOluwa, ed,: P. Singh nee' Nigam and A. Pandey, Palm Oil Industry Residues, In: Biotechnology for AgroIndustrial Residues Utilisation, Springer: Dordrecht (2009).

64. L. Singh, M.N.I. Siddique and A.W. Zularisam, Int. J. Civ. Eng. GeoEnviron., 3, 71 (2012).

65. A. Ibrahim, B. Yeoh, S. Cheah, A. Ma, S. Ahmad, T. Chew, R. Raj and M.J. Wahid, Water Sci. Technol., 17, 155 (1985); https://doi.org/10.2166/wst.1985.0127.

66. M. Reilly, R. Dinsdale and A. Guwy, Bioresour. Technol., 208, 134 (2016); https://doi.org/10.1016/j.biortech.2016.02.060.

67. M.M. Kabir, G. Forgács and I.S. Horváth, Biogas from Lignocellulosic Materials, In: Lignocellulose-Based Bioproducts, Springer: Switzerland pp. 207-251 (2015).

68. V. Moset, D. Fontaine and H.B. Møller, Energy, 141, 451 (2017); https://doi.org/10.1016/j.energy.2017.08.068.

69. N. Rasit, A. Idris, R. Harun and W.A.W. Ab Karim Ghani, Renew. Sustain. Ener. Rev., 45, 351 (2015); https://doi.org/10.1016/j.rser.2015.01.066.

70. A.A.L. Zinatizadeh, A.R. Mohamed, A.Z. Abdullah, M.D. Mashitah, M.H. Isa and G.D. Najafpour, Water Res., 40, 3193 (2006); https://doi.org/10.1016/j.watres.2006.07.005. 
71. M. Basri, S. Yacob, M. Hassan, Y. Shirai, M. Wakisaka, M. Zakaria and L. Phang, World J. Microbiol. Biotechnol., 26, 505 (2010); https://doi.org/10.1007/s11274-009-0197-x.

72. M. Climent, I. Ferrer, M.M. Baeza, A. Artola, F. Vázquez and X. Font, Chem. Eng. J., 133, 335 (2007); https://doi.org/10.1016/j.cej.2007.02.020.

73. K. Chou, I. Norli and A. Anees, Bioresour. Technol., 101, 8616 (2010); https://doi.org/10.1016/j.biortech.2010.06.101.

74. R.A. Alrawi, A. Ahmad, N. Ismail and M.O.A. Kadir, Desalination, 269 , 50 (2011); https://doi.org/10.1016/j.desal.2010.10.041.

75. P. Poh and M. Chong, Biomass Bioener., 67, 231 (2014); https://doi.org/10.1016/j.biombioe.2014.05.007.

76. M. Khemkhao, S. Techkarnjanaruk and C. Phalakornkule, Bioresour. Technol., 177, 17 (2015); https://doi.org/10.1016/j.biortech.2014.11.052.

77. A. Malakahmad and W. Yee, J. Jap. Inst. Ener., 93, 505 (2014); https://doi.org/10.3775/jie.93.505.

78. S. Alawi, B. Zainuri, T. Meisam, Y. Shahrakbah, A.-A. Suraini, H.M. Ali and S. Yoshihito, Am. J. Biochem. Biotechnol., 5, 1 (2009); https://doi.org/10.3844/ajbbsp.2009.1.6.

79. T. Alkhamis, R. El-Khazali, M. Kablan and M. Alhusein, Sol. Energy, 69, 239 (2000): https://doi.org/10.1016/S0038-092X(00)00068-2.

80. L. Moreno, A. González, F. Cuadros-Salcedo and F. Cuadros-Blázquez, J. Clean. Prod., 144, 48 (2017); https://doi.org/10.1016/j.jclepro.2016.12.060.

81. P. Karthika and D. Narayanan, Int. J. Res. Electr. Elec. Eng., 4, 1 (2016).

82. H. Steinfeld, P. Gerber, T. Wassenaar, V. Castel, M. Rosales and C. de Haan, Livestock's Long Shadow: Environmental Issues and Options. Food and Agriculture Organization of the United Nations (FAO), Rome (2006).

83. A. Whiting and A. Azapagic, Energy, 70, 181 (2014); https://doi.org/10.1016/j.energy.2014.03.103.

84. P. Börjesson and M. Berglund, Biomass Bioener, 31, 326 (2007); https://doi.org/10.1016/j.biombioe.2007.01.004.

85. J. Bachmaier, M. Effenberger and A. Gronauer, Eng. Life Sci., 10, 560 (2010); https://doi.org/10.1002/elsc.201000073.

86. U.H. Sidik, F.B. Razali, S.R.W. Alwi and F. Maigari, Nigerian J. Basic Appl. Sci., 21, 79 (2013).

87. S. O-Thong, K. Boe and I. Angelidaki, Appl. Energy, 93, 648 (2012); https://doi.org/10.1016/j.apenergy.2011.12.092.

88. W. Suksong, K. Promnuan, J. Seengenyoung and S. O-Thong, Energy Procedia, 138, 789 (2017); https://doi.org/10.1016/j.egypro.2017.10.068
89. W. Suksong, A. Jehlee, A. Singkhala, P. Kongjan, P. Prasertsan, T. Imai and S. O-Thong, Indus. Crop Prot., 95, 502 (2017); https://doi.org/10.1016/j.indcrop.2016.11.002.

90. W. Suksong, P. Kongjan and S. O-Thong, Energy Proceedia, 79, 943 (2015); https://doi.org/10.1016/i.egypro.2015.11.591.

91. R. Omar, R.M. Harun, T. Mohd Ghazi, W. Wan Azlina, A. Idris and R. Yunus, Proceedings Philadelphia, Annual Meeting of American Institute of Chemical Engineers, pp. 1-10 (2008).

92. G. Najafpour, H.A. Yieng, H. Younesi and A. Zinatizadeh, Process Biochem., 40, 2879 (2005); https://doi.org/10.1016/j.procbio.2005.01.002.

93. N. Oswal, P.M. Sarma, S.S. Zinjarde and A. Pant, Bioresour. Technol., $\mathbf{8 5}, 35$ (2002); https://doi.org/10.1016/S0960-8524(02)00063-9.

94. M. Doble, A. Kumar, Basic Conceptual Models and Reactor Design for Aerobic and Anaerobic Treatment, In: Review of Biotreatment of Industrial Effluents, Elsevier Butterworth-Heinemann, Elsevier Inc.: Burlington (2005)

95. S. Yacob, Y. Shirai, M.A. Hassan, M. Wakisaka and S. Subash, Process Biochem., 41, 962 (2006); https://doi.org/10.1016/j.procbio.2005.10.021.

96. M.N.I. Siddique and Z.B.A. Wahid, Water Environ. Res., 90, 835 (2018); https://doi.org/10.2175/106143017X15131012153031.

97. R. Borja, C.J. Banks and E. Sánchez, J. Biotechnol., 45, 125 (1996) https://doi.org/10.1016/0168-1656(95)00154-9.

98. A.K.M. Omar, A.A. Zuhairi, N.A.R. Nik Norulaini, I.M. Hakimi and M.M. Nazri, J. Ind. Technol., 10, 55 (2001).

99. Q. Xie, W. Taweepreda, C. Musikavong and C. Suksaroj, Songklanakarin J. Sci. Technol., 33, 699 (2011).

100. A. Aygun and T. Yilmaz, Int. J. Chem. Environ. Eng., 1, 97 (2010).

101. W.H. Glaze, J.-W. Kang and D.H. Chapin, Ozone Sci. Eng., 9, 335 (1987); https://doi.org/10.1080/01919518708552148

102. N.H. Abdurahman, Y.M. Rosli and N.H. Azhari, Desalination, 266, 208 (2011); https://doi.org/10.1016/j.desal.2010.08.028

103. A.L. Ahmad, M.F. Chong, S. Bhatia and S. Ismail, Desalination, 191, 35 (2006); https://doi.org/10.1016/j.desal.2005.06.033. 